\title{
Asymmetric Synthesis of All Stereoisomers of the Strigol Analogue GR 24. Dependence of Absolute Configuration on Stimulatory Activity of Striga hermonthica and Orobanche crenata Seed Germination
}

\author{
J an Willem J . F. Thuring, Gerard H. L. Nefkens, and Binne Zwanenburg* \\ NSR-Center for Molecular Structure, Design and Synthesis, Department of Organic Chemistry, \\ University of Nijmegen, Toernooiveld, 6525 ED Nijmegen, The Netherlands
}

\begin{abstract}
All four optically pure stereoisomers of the strigol analogue GR24 were prepared via two different routes. In the first approach enanti opure ABC-fragments $\mathbf{4}$ were used as the chiral source, whereas in the alternative route both antipodes of the latent D-ring $\mathbf{6}$ were employed. Bioassays revealed significant differences in activity between the four stereoisomers in the stimulation of germination of the parasitic weeds Striga hermonthica and Orobanche crenata.
\end{abstract}

Keywords: Striga; Orobanche; germination, GR24

\section{INTRODUCTION}

Parasitic weeds belonging to the genera Striga, Orobanche, and Alectra cause severe damage to several graminaceous and leguminous crops in tropical and semitropical areas of the eastern hemisphere (Musselman, 1987; Parker and Riches, 1993). Seeds of these parasitic weeds usually remain dormant in the soil, but after exposure to a specific germination stimulant, which is exuded by the roots of a suitable host, the seeds germinate and attach to the root system of the host (Press et al., 1990). The stimulation of germination, in particular the compounds by which this process is triggered, has received much attention. The most prominent naturally occurring germination stimulant, viz. (+)-strigol (1) (Figure 1), has been isolated from the root exudate of the fal se host cotton (Gossypium hirsutum L.) (Cook et al., 1966), and its structure was elucidated (Cook et al., 1972). The absolute configuration was unambiguously determined several years later (Brooks et al., 1985). Recently, it has been shown to be the major Striga germination stimulant produced by the true hosts maize (Zea mays L.) and proso millet (Panicum miliaceum L.) (Siame et al., 1993). It was demonstrated that the absolute stereochemistry of strigol $\mathbf{1}$ is of prime importance with respect to seed germination activity (Hauck and Schildknecht, 1990; Bergmann et al., 1993).

In a study to design simpler analogues of (+)-strigol (1) with optimal bioactivity, J ohnson et al. $(1976,1981)$ have prepared the rather readily accessible synthetic anal ogue GR24 (2) (Figure 1). Its racemic preparation and the separation of its diastereomers was improved considerably (Mangnus et al., 1992a; Nefkens et al., 1996). The seed germination stimulatory activity toward several parasitic weed species is within the same order of magnitude as that of strigol (Pepperman et al., 1987; Hauck et al., 1992; Bergmann et al., 1993). For these reasons GR24 (2) has found widespread applications, including its use as a positive control in bioassays of Orobanche and Striga seed germination (Mangnus et al., 1992b). So far, only little attention has been paid to the influence of the absolute stereochemistry of

\footnotetext{
*Fax +31.24.3652929; e-mail zwanenb@sci.kun.nl
}

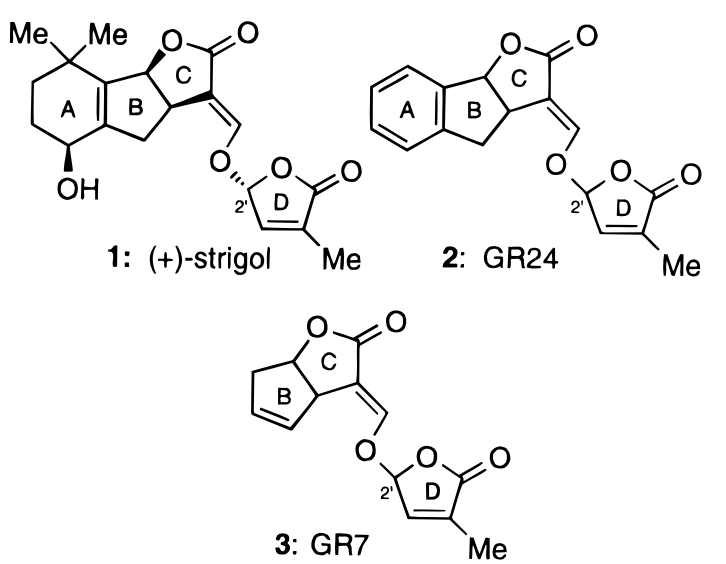

Figure 1. Structures of (+)-strigol (1) and synthetic strigol analogues $\mathbf{2}$ and $\mathbf{3}$.

synthetic strigol analogues on the biological activity. Recently, all four stereoisomers of GR7 (3), a strigol analogue lacking the A-ring, have been prepared and tested on seed germination activity (Mangnus and Zwanenburg, 1992). It was concluded that the correct absolute stereochemistry at C-2' (R-configuration) is essential to exert maximal bioactivity.

The present paper deals with the asymmetric syntheses of all four stereoisomers of GR24 (2) and their germination activities on seeds of Striga hermonthica (Del.) Benth and Orobanche crenata Forsk.

\section{MATERIALS AND METHODS}

Nomenclature. The AUTONOM 1.0 program, provided by the Beilstein Institute and Springer-Verlag (Weinheim, Germany) was used.

Syntheses. General Remarks. ${ }^{1} \mathrm{H}-\mathrm{NMR}(100 \mathrm{MHz}$ and 400 $\mathrm{MHz}$ ) spectra were recorded on Bruker AC 100 and Bruker AM-400 spectrometers, respectively $\left(\mathrm{Me}_{4} \mathrm{Si}\right.$ as internal standard), both from Bruker (Wissembourg, F rance). All coupling constants are given as ${ }^{3} \mathrm{~J}$ in hertz, unless indicated otherwise. F or mass spectra a double-focusing VG7070E mass spectrometer from VG Analytical (Manchester, U.K.) was used. Optical rotations were measured on a Perkin-Elmer 241 polarimeter. Elemental analyses were performed at the Department of Micro-analysis of this laboratory.

Solvents were dried using the following methods: Dichloromethane was distilled from $\mathrm{P}_{2} \mathrm{O}_{5}$. Diethyl ether was distilled 
from $\mathrm{NaH}$. Hexane was distilled from $\mathrm{CaH}_{2}$. Tetrahydrofuran was distilled from lithium al uminum hydride just before use. All other solvents were of analytical grade. Thin layer chromatography (TLC) was carried out on Merck precoated silica gel $60 \mathrm{~F} 254$ plates $(0.25 \mathrm{~mm})$ using the eluents indicated. Spots were visualized with UV or using a molybdate spray. "Flash" chromatography was carried out at a pressure of ca. 1.5 bar, using Merck Kieselgel $60 \mathrm{H}$. Column chromatography at atmospheric pressure was carried out, using Merck Kieselgel 60.

Sodium hydride $(60 \%$ in dispersion oil) was washed twice with hexane just before use. 3,3a,4,8b-Tetrahydroindeno[1,2b]furan-2-one ( $\operatorname{rac} 4$ ) and 5-bromo-3-methyl-2(5H)-furanone (5) were prepared following published methods (Mangnus et al., 1992a). The synthesis of chlorolactones 6 and ent 6 was reported previously (Thuring et al., 1995).

For the resolution of rac $\mathbf{4}$ microcrystalline cellulose triacetate (particle size 25-40 $\mu \mathrm{m}$ ) from Fluka (Buchs, Switserland) was used. The enantiopurities of $\mathbf{4}$ and ent 4 were determined by HPLC analysis using an Spectra Physics SP8700 HPLC apparatus (Spectra Physics, Eindhoven, The Netherlands), a chiral Baker Chiralcel OD-H column [eluent hexane/ethanol 60:40 (v/v), flow rate $0.5 \mathrm{~mL} / \mathrm{min}$ ], and an LKB 2138 U vicord S UV - vis detector ( $254 \mathrm{~nm}$ ) (Pharmacia Biotech., Roozendaal, The Netherlands).

Chromatographic Resol ution of 3,3a,4,8b-Tetrahydroindeno[1,2-b]furan-2-one (rac 4). The sorbent CTA (50 g) was swollen before use by heating in $\mathrm{EtOH} / \mathrm{H}_{2} \mathrm{O} 95: 5(150 \mathrm{~mL})$ at ca. $75^{\circ} \mathrm{C}$ for $20 \mathrm{~min}$. A glass column (i.d. $2.5 \mathrm{~cm}$ ) was slurry-packed with this material, and the stationary phase was eluted with $95 \% \mathrm{EtOH}$ at a pressure of ca. 1.2 bar. The racemic lactone rac 4 (500 mg), dissolved in 95\% EtOH (3 mL), was chromatographically resolved, using $95 \% \mathrm{EtOH}$ as the eluent. Fractions of ca. $5 \mathrm{~mL}$ were collected, their optical rotations were recorded, and they were analyzed for enanti omeric excess (ee) by chiral HPLC: yield, $170 \mathrm{mg}$ (34\%) of pure fast-moving enantiomer $4\left(t_{R}=11.30 \mathrm{~min}\right)$ as a white solid; $[\alpha]_{D}-107.0^{\circ}$ (c $0.4, \mathrm{CHCl}_{3}$ ), ee > 98\%.

The slow-moving enantiomer, ent $4(170 \mathrm{mg}, 34 \%)\left(\mathrm{t}_{\mathrm{R}}=\right.$ $12.18 \mathrm{~min}$ ), was obtained as a white solid: $[\alpha]_{\mathrm{D}}+102.5^{\circ}$ (c 0.4 , $\left.\mathrm{CHCl}_{3}\right)$, ee $>98 \%$.

Formylation of $3 a(R), 8 b(S)-4$ and Coupling with 5-Bromo3-methyl-2(5H)-furanone 5 (General Procedure). Potassium tert-butoxide (131 mg, $1.17 \mathrm{mmol}$ ) was added to a solution of lactone 4 (185 mg, $1.06 \mathrm{mmol}$ ) and methyl formate (1.6 mmol) in THF $(5 \mathrm{~mL})$ with stirring at $0{ }^{\circ} \mathrm{C}$ under nitrogen. Stirring was continued for $18 \mathrm{~h}$ at room temperature, followed by the addition of a solution of furanone 5 (207 $\mathrm{mg}, 1.17 \mathrm{mmol})$ in THF $(10 \mathrm{~mL})$ at $0{ }^{\circ} \mathrm{C}$ under nitrogen. After $18 \mathrm{~h}$ of stirring, precipitated potassium bromide was removed by filtration. The filtrate was concentrated in vacuo, and the residue was dissolved in a mixture of water $(5 \mathrm{~mL})$ and chlor oform $(10 \mathrm{~mL})$. The aqueous phase was extracted with chloroform (three times). The combined organic layers were dried $\left(\mathrm{MgSO}_{4}\right)$ and concentrated in vacuo. The crude yellow oil was purified by flash chromatography $\left(\mathrm{SiO}_{2}\right.$, diisopropyl ether/ethyl acetate 4:1) to give two separated diastereomeric products, 2a and ent $\mathbf{2 b}$, as white solids.

3-[4-Methyl-5-oxo-2,5-dihydr ofuran-2(R)-yl oxymethylene]3,3a(R),4,8b(S)-tetrahydroindeno[1,2-b]furan-2-one (2a) and I ts 2'(S)-E pimer (ent $\mathbf{2 b}$ ). These compounds were prepared according to the general procedure to give $\mathbf{2 a}, 92 \mathrm{mg}$ (yield $29 \%$ ), and ent $\mathbf{2 b}, 95 \mathrm{mg}$ (yield 30\%). Analytically pure samples were obtained by crystallization from hexane/ethyl acetate.

2a: obtained as colorless crystals; mp $154-155{ }^{\circ} \mathrm{C}$; $[\alpha]_{D}$ $+436^{\circ}$ (c $0.25, \mathrm{CHCl}_{3}$ ); $\mathrm{R}_{\mathrm{f}} 0.32$ (hexane/ethyl acetate $1: 1$ ); ${ }^{1} \mathrm{H}$ NMR $\left(\mathrm{CDCl}_{3}, 400 \mathrm{MHz}\right) \delta 2.05\left(\mathrm{~m}, 3 \mathrm{H}, \mathrm{CH}_{3}\right), 3.11$ (dd, $1 \mathrm{H},{ }^{2} \mathrm{~J}$ $\left.=16.8 \mathrm{~Hz}, \mathrm{~J}=3.3 \mathrm{~Hz}, \mathrm{H}_{4}\right), 3.44(\mathrm{dd}, 1 \mathrm{H}, 2 \mathrm{~J}=16.8 \mathrm{~Hz}, \mathrm{~J}=9.2$ $\left.\mathrm{Hz}, \mathrm{H}_{4}\right), 3.95\left(\mathrm{~m}, 1 \mathrm{H}, \mathrm{H}_{3 \mathrm{a}}\right), 5.96\left(\mathrm{~d}, 1 \mathrm{H}, \mathrm{J}=7.8 \mathrm{~Hz}, \mathrm{H}_{8 b}\right), 6.18$ (m, $1 \mathrm{H}$, OCHO D-ring), $6.97(\mathrm{~m}, 1 \mathrm{H},=\mathrm{CH}$ D-ring), 7.23-7.36 $(\mathrm{m}, 3 \mathrm{H}, \mathrm{Ar} \mathrm{H}), 7.48(\mathrm{~d}, 1 \mathrm{H}, 4 \mathrm{~J}=2.5 \mathrm{~Hz},=\mathrm{CHO}), 7.51(\mathrm{~d}, 1 \mathrm{H}$, $\mathrm{J}=7.1 \mathrm{~Hz}, \mathrm{Ar} \mathrm{H})$; MS [EI, m/z, rel intensity (\%)] 298 ([M] ${ }^{+}$, 0.4), $201\left(\left[\mathrm{C}_{12} \mathrm{H}_{9} \mathrm{O}_{3}\right]^{+}, 39.3\right), 97\left(\left[\mathrm{C}_{5} \mathrm{H}_{5} \mathrm{O}_{2}\right]^{+}, 100\right)$. Anal. Calcd for $\mathrm{C}_{17} \mathrm{H}_{14} \mathrm{O}_{5}$ : C, 68.45; $\mathrm{H}, 4.73$. Found: $\mathrm{C}, 68.22 ; \mathrm{H}, 4.63$.

ent 2b: obtained as colorless crystals; $\mathrm{mp} 133.5-134.5^{\circ} \mathrm{C}$; $[\alpha]_{\mathrm{D}}+273^{\circ}\left(\mathrm{c} 0.2, \mathrm{CHCl}_{3}\right) ; \mathrm{R}_{\mathrm{f}} 0.24$ (hexane/ethyl acetate 1:1);
${ }^{1} \mathrm{H} \mathrm{NMR}\left(\mathrm{CDCl}_{3}, 400 \mathrm{MHz}\right) \delta 2.05\left(\mathrm{~m}, 3 \mathrm{H}, \mathrm{CH}_{3}\right), 3.10$ (dd, $1 \mathrm{H}$, 2J $\left.=16.9 \mathrm{~Hz}, \mathrm{~J}=3.1 \mathrm{~Hz}, \mathrm{H}_{4}\right), 3.42\left(\mathrm{dd}, 1 \mathrm{H},{ }^{2} \mathrm{~J}=16.9 \mathrm{~Hz}\right.$, J $=$ $\left.9.3 \mathrm{~Hz}, \mathrm{H}_{4}\right), 3.94\left(\mathrm{~m}, 1 \mathrm{H}, \mathrm{H}_{3 \mathrm{a}}\right), 5.96\left(\mathrm{~d}, 1 \mathrm{H}, \mathrm{J}=7.9 \mathrm{~Hz}, \mathrm{H}_{8 b}\right)$, $6.17(\mathrm{~m}, 1 \mathrm{H}, \mathrm{OCHO}$ D-ring), $6.96(\mathrm{~m}, 1 \mathrm{H},=\mathrm{CH}$ D-ring), $7.23-$ $7.36(\mathrm{~m}, 3 \mathrm{H}, \mathrm{Ar} \mathrm{H}), 7.48$ (d, $\left.1 \mathrm{H},{ }^{4} \mathrm{~J}=2.5 \mathrm{~Hz},=\mathrm{CHO}\right), 7.50(\mathrm{~d}$, $1 \mathrm{H}, \mathrm{J}=7.5 \mathrm{~Hz}, \mathrm{Ar} \mathrm{H}$ ); mass data were the same as for $\mathbf{2 a}$. Anal. Calcd for $\mathrm{C}_{17} \mathrm{H}_{14} \mathrm{O}_{5}$ : C, 68.45; $\mathrm{H}, 4.73$. Found: $\mathrm{C}, 68.31$; $\mathrm{H}, 4.68$.

3-[4-Methyl-5-oxo-2,5-dihydrofuran-2(R)-yl oxymethylene]3,3a(S),4,8b(R)-tetrahydroindeno[1,2-b]furan-2-one (2b) and Its 2'(S)-E pimer (ent 2a). These compounds were prepared according to the general procedure, starting from lacone ent $\mathbf{4}$ (186 $\mathrm{mg}, 1.07 \mathrm{mmol}$ ) to give $\mathbf{2 b}$ (yield = 33\%) and ent $\mathbf{2 a}$ (yield $=27 \%)$. Analytically pure samples were obtained by crystallization from hexane/ethyl acetate.

2b: obtained as colorless crystals; mp $133.5-134{ }^{\circ} \mathrm{C}$; $[\alpha]_{\mathrm{D}}$ $-272^{\circ}$ (c $0.2, \mathrm{CHCl}_{3}$ ). Anal. Calcd for $\mathrm{C}_{17} \mathrm{H}_{14} \mathrm{O}_{5}$ : C, 68.45; $\mathrm{H}$, 4.73. Found: $\mathrm{C}, 68.26 ; \mathrm{H}, 4.66$. $^{1} \mathrm{H}-\mathrm{NMR}$ and mass data were the same as for compound ent $\mathbf{2} \mathbf{b}$.

ent 2a: obtained as colorless crystals; mp $152.5-154.5^{\circ} \mathrm{C}$; $[\alpha]_{D}-446^{\circ}$ (c 0.25, $\mathrm{CHCl}_{3}$ ). Anal. Calcd for $\mathrm{C}_{17} \mathrm{H}_{14} \mathrm{O}_{5}: \mathrm{C}, 68.45$; $H, 4.73$. Found: $C, 68.12 ; H, 4.67$. ${ }^{1} H-N M R$ and mass data were the same as for compound $\mathbf{2 a}$.

Determination of Enantiopurities. ${ }^{1} \mathrm{H}-\mathrm{NMR}(400 \mathrm{MHz})$ analysis of racemic mixtures of diastereomers $\mathbf{2} \mathbf{a}$ and $\mathbf{2} \mathbf{b}$ with optical shift reagent $\mathrm{Eu}(\mathrm{hfc})_{3}(0.5$ equiv) revealed a downfield shift for all resonances, with a prominent 1:1 splitting of the signal for the enol ether proton $(=\mathrm{CH}-\mathrm{O})$, amounting to 0.35 ppm. ${ }^{1} \mathrm{H}-\mathrm{NMR}(400 \mathrm{MHz})$ spectra of pure compounds $\mathbf{2 a ,} \mathbf{b}$ and ent $\mathbf{2 a}, \mathbf{b}$ displayed comparable shifts on treatment with $\mathrm{Eu}$ $(\mathrm{hfc})_{3}$, but in contrast to the racemates, no splitting of signals was observed, indicating an enantiopurity of at least $98 \%$.

3-[6(S)-Methyl-5-oxo-4-oxatricyclo[5.2.1.0 2,6]dec-8-en-3(R)yloxymethylene]-3,3a(R),4,8b(S)-tetrahydroindeno[1,2-b]furan2-one (7a) and Its $3 a(S), 8 b(R)$ Diastereomer $(\mathbf{7 b})$. To a stirred suspension of $\mathrm{NaH}$ (139 mg, $3.48 \mathrm{mmol}$ ) in diethyl ether (10 $\mathrm{mL}$ ) was gradually added a solution of rac 4 (300 mg, 1.72 $\mathrm{mmol})$ in diethyl ether $(5 \mathrm{~mL})$ at room temperature under nitrogen. Ethyl formate $(1.7 \mathrm{~mL}, 21 \mathrm{mmol})$ was added, and stirring was continued for $15 \mathrm{~h}$. The solvent was removed in vacuo. The thus obtained sodium salt was dissolved in DMF $(10 \mathrm{~mL})$. A solution of chlorolactone $6(372 \mathrm{mg}, 1.87 \mathrm{mmol})$ in DMF ( $3 \mathrm{~mL}$ ) was gradually added at room temperature under nitrogen. After $17 \mathrm{~h}$ of stirring, the mixture was quenched with acetic acid $(0.5 \mathrm{~mL})$ and the solvent was removed in vacuo. The residue was dissolved in a mixture of water and ethyl acetate. The aqueous phase was extracted with ethyl acetate (two times), and the combined organic layers were washed with water (two times), dried $\left(\mathrm{MgSO}_{4}\right)$, and concentrated in vacuo. The crude product was purified using flash chromatography $\left(\mathrm{SiO}_{2}\right.$, hexane/ethyl acetate 2:1) to afford two diastereomeric products. The fast-moving diastereomer $\mathbf{7 a}$ (222 mg, 35\%) was obtained as a white solid, and crystallization from dii sopropyl ether/ethyl acetate afforded analytically pure 7a. The slow-moving diastereomer $7 \mathbf{b}$ (211 mg, 34\%) was obtained as a white solid, which gave an analytically pure sample after crystallization from hexane/ethyl acetate.

7a: $\mathrm{mp} 174-177{ }^{\circ} \mathrm{C} ;[\alpha]_{\mathrm{D}}+276^{\circ}$ (c $0.1, \mathrm{CHCl}_{3}$ ); $\mathrm{R}_{\mathrm{f}} 0.48$ (hexane/ethyl acetate 1:1); ${ }^{1} \mathrm{H}$ NMR $\left(\mathrm{CDCl}_{3}, 100 \mathrm{MHz}\right) \delta 1.61$ $\left(\mathrm{s}, 3 \mathrm{H}, \mathrm{CH}_{3}\right), 1.74\left(\mathrm{~m}, 2 \mathrm{H}, \mathrm{H}_{10}\right), 2.74(\mathrm{dd}, 1 \mathrm{H}, \mathrm{J}=4.2 \mathrm{~Hz}, \mathrm{~J}<$ $\left.1 \mathrm{~Hz}, \mathrm{H}_{2}\right), 2.91\left(\mathrm{~m}, 1 \mathrm{H}, \mathrm{H}_{7}\right), 3.09\left(\mathrm{dd}, 1 \mathrm{H},{ }^{2} \mathrm{j}=16.8 \mathrm{~Hz}, \mathrm{~J}=\right.$ $3.8 \mathrm{~Hz}, \mathrm{CH}_{2}$ B-ring), $3.24\left(\mathrm{~m}, 1 \mathrm{H}, \mathrm{H}_{1}\right), 3.46\left(\mathrm{dd}, 1 \mathrm{H},{ }^{2} \mathrm{~J}=16.8\right.$ $\mathrm{Hz}, \mathrm{J}=8.9 \mathrm{~Hz}, \mathrm{CH}_{2}$ B-ring), $3.93\left(\mathrm{~m}, 1 \mathrm{H}, \mathrm{H}_{3 \mathrm{a}}\right), 5.23(\mathrm{~d}, 1 \mathrm{H}, \mathrm{J}$

$\left.<1 \mathrm{~Hz}, \mathrm{H}_{3}\right), 5.94\left(\mathrm{~d}, 1 \mathrm{H}, \mathrm{J}=7.8 \mathrm{~Hz}, \mathrm{H}_{8 \mathrm{~b}}\right), 6.25\left(\mathrm{~m}, 2 \mathrm{H}, \mathrm{H}_{8}\right.$ and $\left.\mathrm{H}_{9}\right), 7.27-7.55(\mathrm{~m}, 4 \mathrm{H}, \mathrm{Ar} \mathrm{H}), 7.40(\mathrm{~d}, 1 \mathrm{H}, 4 \mathrm{~J}=2.5 \mathrm{~Hz},=\mathrm{CHO})$; MS [El, m/z, rel intensity (\%)] $364\left([\mathrm{M}]^{+}, 0.3\right), 299\left(\left[\mathrm{C}_{17} \mathrm{H}_{15} \mathrm{O}_{5}\right]^{+}\right.$, 0.3), $203\left(\left[\mathrm{C}_{12} \mathrm{H}_{11} \mathrm{O}_{3}\right]^{+}, 27.1\right), 163\left(\left[\mathrm{C}_{10} \mathrm{H}_{11} \mathrm{O}_{2}\right]^{+}, 93.2\right), 97$ $\left(\left[\mathrm{C}_{5} \mathrm{H}_{5} \mathrm{O}_{2}\right]^{+}, 100\right), 66\left(\left[\mathrm{C}_{5} \mathrm{H}_{6}\right]^{+}, 15.6\right)$. Anal. Calcd for $\mathrm{C}_{22} \mathrm{H}_{20} \mathrm{O}_{5}$ : C, 72.52; $\mathrm{H}, 5.53$. Found: $\mathrm{C}, 72.11 ; \mathrm{H}, 5.46$.

7b: $\mathrm{mp} 192.5-194.5^{\circ} \mathrm{C}$; $[\alpha]_{D}-334^{\circ}$ (c $0.1, \mathrm{CHCl}_{3}$ ); $\mathrm{R}_{\mathrm{f}} 0.36$ (hexane/ethyl acetate 1:1); ${ }^{1} \mathrm{H}$ NMR $\left(\mathrm{CDCl}_{3}, 100 \mathrm{MHz}\right) \delta 1.63$ (s, 3H, $\left.\mathrm{CH}_{3}\right), 1.73\left(\mathrm{~m}, 2 \mathrm{H}, \mathrm{H}_{10}\right), 2.78(\mathrm{dd}, 1 \mathrm{H}, \mathrm{J}=3.7 \mathrm{~Hz}, \mathrm{~J}<$ $\left.1 \mathrm{~Hz}, \mathrm{H}_{2}\right), 2.91\left(\mathrm{~m}, 1 \mathrm{H}, \mathrm{H}_{7}\right), 3.05\left(\mathrm{dd}, 1 \mathrm{H},{ }^{2} \mathrm{j}=16.8 \mathrm{~Hz}, \mathrm{~J}=\right.$ $3.5 \mathrm{~Hz}, \mathrm{CH}_{2}$ B-ring), $3.24\left(\mathrm{~m}, 1 \mathrm{H}, \mathrm{H}_{1}\right), 3.42\left(\mathrm{dd}, 1 \mathrm{H},{ }^{2} \mathrm{~J}=16.8\right.$ $\mathrm{Hz}, \mathrm{J}=8.8 \mathrm{~Hz}, \mathrm{CH}_{2}$ B-ring), $3.93\left(\mathrm{~m}, 1 \mathrm{H}, \mathrm{H}_{3 \mathrm{a}}\right), 5.24(\mathrm{~d}, 1 \mathrm{H}$, J $\left.<1 \mathrm{~Hz}, \mathrm{H}_{3}\right), 5.95\left(\mathrm{~d}, 1 \mathrm{H}, \mathrm{J}=7.9 \mathrm{~Hz}, \mathrm{H}_{8 b}\right), 6.26\left(\mathrm{~m}, 2 \mathrm{H}, \mathrm{H}_{8}\right.$ and 


\section{Scheme 1. Resolution of rac 4 and Coupling with 5}

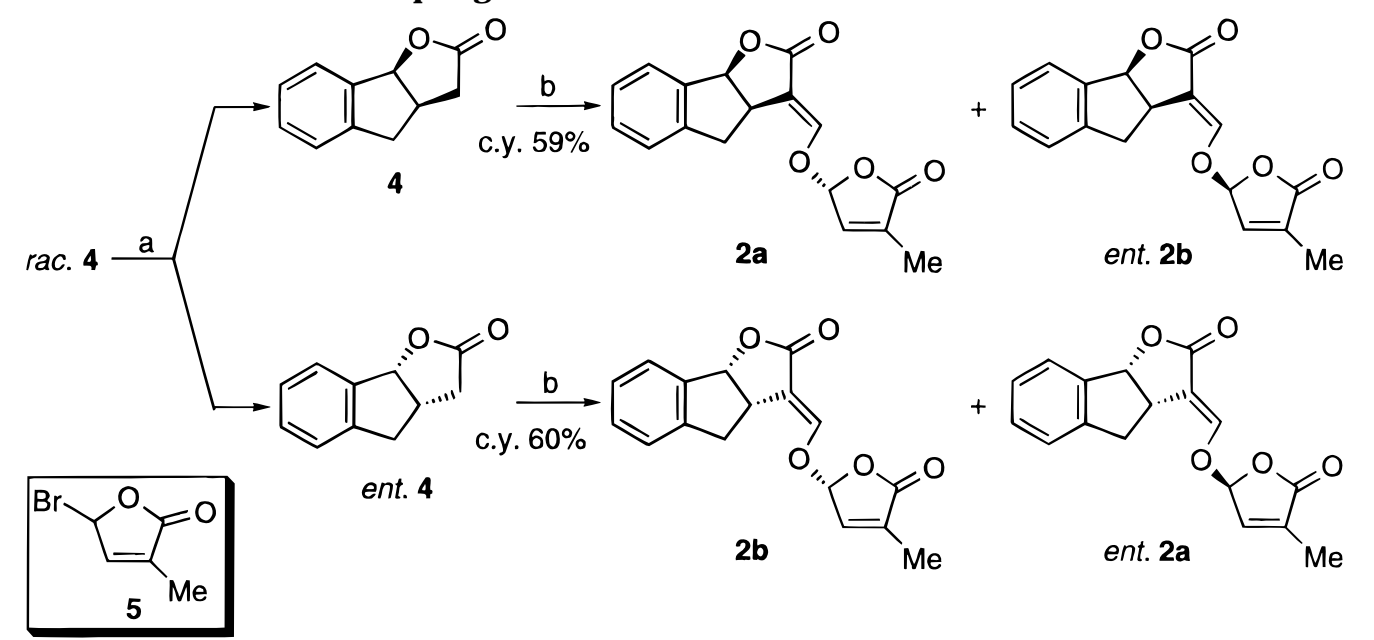

a) cellulose triacetate chromatography, b) 1. $\mathrm{KOtBu}, \mathrm{HCO}_{2} \mathrm{Me} 2.5$

$\left.\mathrm{H}_{9}\right), 7.21-7.53(\mathrm{~m}, 4 \mathrm{H}, \mathrm{Ar} \mathrm{H}), 7.39(\mathrm{~d}, 1 \mathrm{H}, 4 \mathrm{~J}=2.8 \mathrm{~Hz},=\mathrm{CHO})$; mass data were the same as for $7 a$. Anal. Calcd for $\mathrm{C}_{22} \mathrm{H}_{20} \mathrm{O}_{5}$ : C, 72.52; $\mathrm{H}, 5.53$. Found: $\mathrm{C}, 71.91 ; \mathrm{H}, 5.47$.

3-[6(R)-M ethyl-5-oxo-4-oxatricycl o[5.2.1.02,6]dec-8-en-3(S)yl oxymethylene]-3,3a(R),4,8b(S)-tetrahydroindeno[1,2-b]furan2-one (ent 7b) and Its $3 a(S), 8 b(R)$ Diastereomer (ent 7a). These compounds were prepared in the same way as described for $\mathbf{7 a}$ and $\mathbf{7 b}$, starting from rac 4 (302 $\mathrm{mg}, 1.73 \mathrm{mmol}$ ) and chlorolactone ent $\mathbf{6}(379 \mathrm{mg}, 1.91 \mathrm{mmol})$. The fast-moving diastereomer ent $7 a$ (202 mg, 32\%) was obtained as a white solid, and crystallization from diisopropyl ether/ethyl acetate afforded analytically pure ent 7a. The slow-moving diastereomer ent 7b (215 mg, 34\%) was obtained as a white solid, which gave an analytically pure sample after crystallization from hexane/ethyl acetate.

ent 7a: $\mathrm{mp} 171-173.5^{\circ} \mathrm{C} ;[\alpha]_{\mathrm{D}}-278^{\circ}$ (c $0.1, \mathrm{CHCl}_{3}$ ). Anal. Calcd for $\mathrm{C}_{22} \mathrm{H}_{20} \mathrm{O}_{5}$ : C, 72.52; $\mathrm{H}, 5.53$. Found: $\mathrm{C}, 72.58 ; \mathrm{H}$, 5.45. ${ }^{1} \mathrm{H}-\mathrm{NMR}$ and mass data were the same as for compound 7 .

ent 7b: $\mathrm{mp} 193-193.5^{\circ} \mathrm{C} ;[\alpha]_{\mathrm{D}}+340^{\circ}$ (c 0.1, $\mathrm{CHCl}_{3}$ ). Anal. Calcd for $\mathrm{C}_{22} \mathrm{H}_{20} \mathrm{O}_{5}$ : C, 72.52; $\mathrm{H}, 5.53$. Found: $\mathrm{C}, 72.17 ; \mathrm{H}$, 5.53. ${ }^{1} \mathrm{H}-\mathrm{NMR}$ and mass data were the same as for compound 7b.

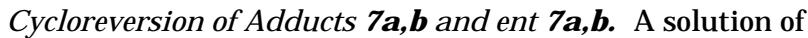
the enantiopure cycloadduct 7 (93 $\mathrm{mg}, 0.26 \mathrm{mmol}$ ) in odichlorobenzene $(40 \mathrm{~mL})$ was heated at $180^{\circ} \mathrm{C}$ for $14 \mathrm{~h}$. The solvent was removed in vacuo. The residue was purified by flash chromatography $\left(\mathrm{SiO}_{2}\right.$, hexane/ethyl acetate 2:1) to give the corresponding enantiomer of 2 (44 mg, 58\%) as a solid. All enantiomers of $\mathbf{2}$ prepared via this procedure showed identical physical and chiroptical properties as described above.

Biological Activity. Seeds. Seeds of Striga hermonthica [from Sorghum bicol or (L.) Moench] and Orobanche crenata (from Vicia faba L.) were harvested in Burkina Faso in 1994 and in Egypt in 1991, respectively, and were stored in the dark at room temperature until use in germination tests. Bioassays were carried out essentially following the procedure of Mangnus et al. (1992b) with minor modifications. Only analytically pure samples as judged from correct el emental analyses were used in these experiments.

Preparation of Test Solutions. A compound to be tested was weighed out very accurately to the amount of $2.5 \mathrm{mg}$, dissolved in $5 \mathrm{~mL}$ of acetone p.a., and diluted with demineralized water to $25 \mathrm{~mL}$. Aliquots of this stock solution were further diluted with water to obtain test solutions containing $1,0.5,0.1,0.05$, and $0.001 \mathrm{mg} / \mathrm{L}$ test compound and $0.2,0.1,0.02,0.01$, and $0.0002 \%(\mathrm{v} / \mathrm{v})$ acetone, respectively.

Bioassays. F or surface sterilization seeds of $\mathrm{S}$. hermonthica were subsequently exposed to $70 \%(\mathrm{v} / \mathrm{v})$ ethanol for $5 \mathrm{~min}$ and sodium hypochlorite ( $2 \%$ active chlorine) for $2 \mathrm{~min}$ with agitation. Seeds of $\mathrm{O}$. crenata were exposed to an aqueous solution of sodium hypochlorite ( $2 \%$ active chlorine) for $5 \mathrm{~min}$ with agitation. The seeds were then thoroughly rinsed with water and dried.

F or conditioning the sterilized seeds were spread on glass fiber filter paper disks (8-mm diameter; approximately 3070 seeds per disk) in Petri dishes, each containing two disks (Striga) or four disks (Orobanche), wetted with water, and stored in the dark for 14 days at $20^{\circ} \mathrm{C}$ for Orobanche seeds and at $30^{\circ} \mathrm{C}$ for Striga seeds. Then the conditioning water was removed and replaced by $100 \mu \mathrm{L}$ of test solution per disk (Orobanche) or $3 \mathrm{~mL}$ per Petri dish (Striga). After incubation for $24 \mathrm{~h}$ (Striga) and 5 days (Orobanche) in the dark at the indicated temperatures, the germination percentage was determined under a microscope. Seeds were considered to be germinated if the radical protruded through the seed coat.

In each test series aqueous solutions with $0.2 \%(\mathrm{v} / \mathrm{v})$ acetone were used as negative control. Test solutions of a 1:1 diastereomeric mixture of GR24 at the same concentrations were used as positive controls. All tests were performed in duplicate, and in each test the germination percentages were determined on 6 disks (Striga) or 12 disks (Orobanche) per treatment.

\section{RESULTS AND DISCUSSION}

Synthesis. To achieve the resolution of GR24 (2), two synthetic approaches were considered. The first approach (Scheme 1) involves the separation of tricyclic lactone rac $\mathbf{4}$ into its enantiomers, followed by formylation and coupling of the individual enantiomers with racemic 5-bromofuranone (5) in an analogous manner as described previously for the racemic preparation of GR24 (Mangnus et al., 1992a).

Tricyclic lactone rac 4 was chromatographically resolved using cellulose triacetate (CTA) as the chiral stationary phase. It has been demonstrated that a wide variety of racemic $\gamma$ - and $\delta$-lactones can be separated by column chromatography on the chiral phase CTA, on both analytic and preparative scales (Francotte and Lohmann, 1987). In the present case $500 \mathrm{mg}$ of rac 4 was resolved by "flash" chromatography at a pressure of ca. 1.2 bar, using $50 \mathrm{~g}$ of CTA and $95 \%$ ethanol as the eluent, in a total recovery of enantiopure tricyclic lactones $\mathbf{4}$ and ent $\mathbf{4}$ of $68 \%$. The enantiopurity of $\mathbf{4}$ and ent 4 was assessed by HPLC, using cellulose carbamate as the chiral stationary phase. The diastereomeric mixtures obtained after formylation and coupling of $\mathbf{4}$ and ent 4 with 5 (Scheme 1) were both separated by flash chromatography $\left(\mathrm{SiO}_{2}\right)$ to give $\mathbf{2 a}$, ent $\mathbf{2 b}$ and $\mathbf{2 b}$, and ent $\mathbf{2 a}$ (ee values $>98 \%$ ) in total isolated yiel ds of $59 \%$ and $60 \%$, respectively. The ee values were determined by ${ }^{1} \mathrm{H}$ NMR using the chiral shift reagent $\mathrm{Eu}(\mathrm{hfC})_{3}$. 
Scheme 2. Coupling Reactions of rac 4 with 6 and ent 6 and Cycloreversion

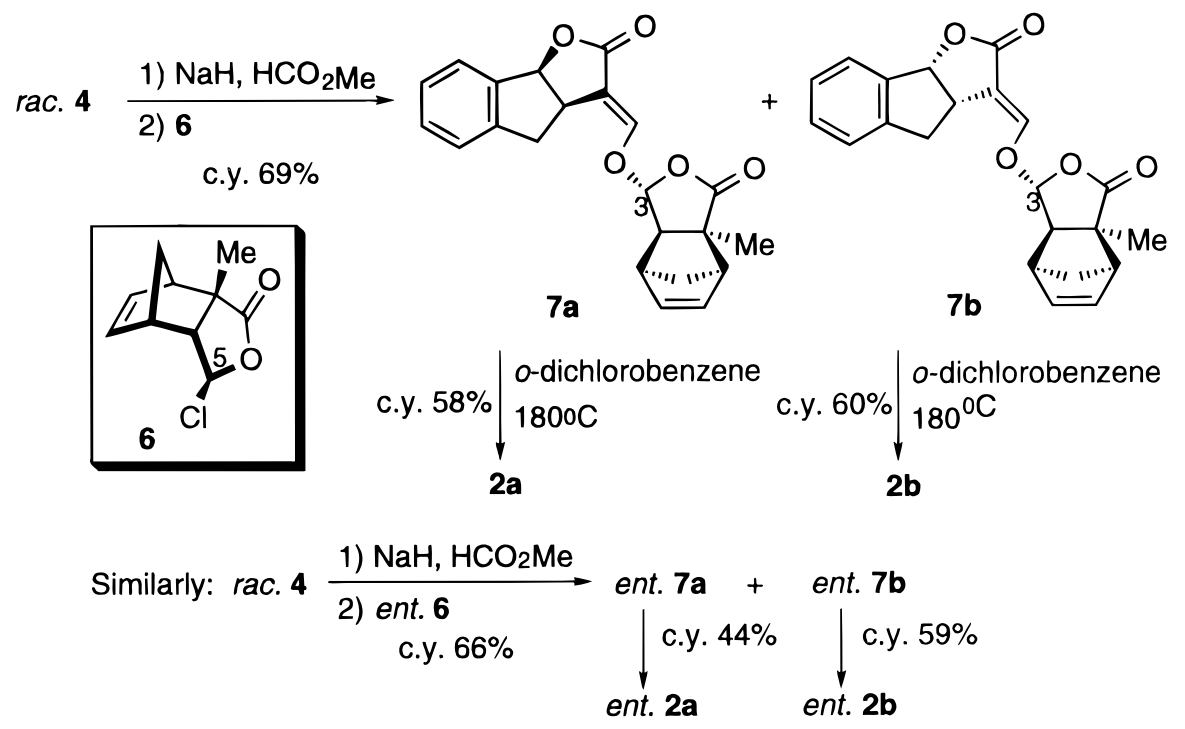

In the second approach the complete resolution of GR24 (2) was accomplished by formylation of rac 4, followed by coupling with the homochiral latent D-rings 6 and ent 6, respectively (Scheme 2).

The asymmetric syntheses of $\mathbf{6}$ and ent $\mathbf{6}$, together with their application in the preparation of all four homochiral diastereomers of GR7 (3), have recently been described (Thuring et al., 1995). The sequence as outlined in Scheme 2 gave the cycloadducts $\mathbf{7 a}$ and $\mathbf{7 b}$ and their corresponding enantiomers in diastereomeric ratios of approximately 1:1. These reactions proceeded with complete stereocontrol as no signals arising from the respective $\mathrm{C}_{3}$-epimers could be detected in the NMR spectra. Cycloreversion by heating the homochiral adducts of 7 in o-dichlorobenzene at $180^{\circ} \mathrm{C}$ afforded the corresponding enantiopure stereoisomers of GR24 (2), which have the same $[\alpha]_{D}$ values as those prepared by the route depicted in Scheme 1. It was essential to control the reaction temperature and time carefully to avoid concomitant epimerization at $\mathrm{C}_{2^{\prime}}$ of $\mathbf{2}$.

Determination of Absolute Configuration. It was attempted to establish the absolute configuration of the GR24 (2) stereoi somers by comparison of their circular dichroism (CD) spectra with those of the corresponding stereoisomers of strigol $\mathbf{1}$, which have been reported (Heather et al., 1976; F rischmuth et al., 1993). However, such a correlation is not reliable, because GR24 (2) has a different ABC-chromophore. Therefore, an X-ray diffraction analysis of $\mathbf{2 a}$ was undertaken (Moers et al., 1995) to establish its absol ute configuration. A stereoview of $\mathbf{2 a}$ is depicted in Figure 2. With the absol ute configuration of $\mathbf{2 a}$ known, the configuration of the remaining stereoisomers could be assigned on the basis of the synthetic sequence.

Biological Activity. The germination stimulatory activity of all stereoisomers of GR24 2a,b and ent $\mathbf{2 a , b}$ was assayed using seeds of $\mathrm{S}$. hermonthica and $\mathrm{O}$. crenata. In each bioassay a diastereomeric mixture of GR24 was included as a positive control. In preliminary experiments the concentration-dependent activity range (GR24) of seeds of S. hermonthica has been established. Maximal germination percentages were obtained within the concentration range $0.01-1 \mathrm{mg} / \mathrm{L}$. Half-maximal activity was observed at approximately $0.001 \mathrm{mg} / \mathrm{L}$ (data not shown). The relative bioactivity of the individual stereoisomers of GR24 was therefore assayed at an optimal concentration $(0.1 \mathrm{mg} / \mathrm{L})$ and at a sensitive

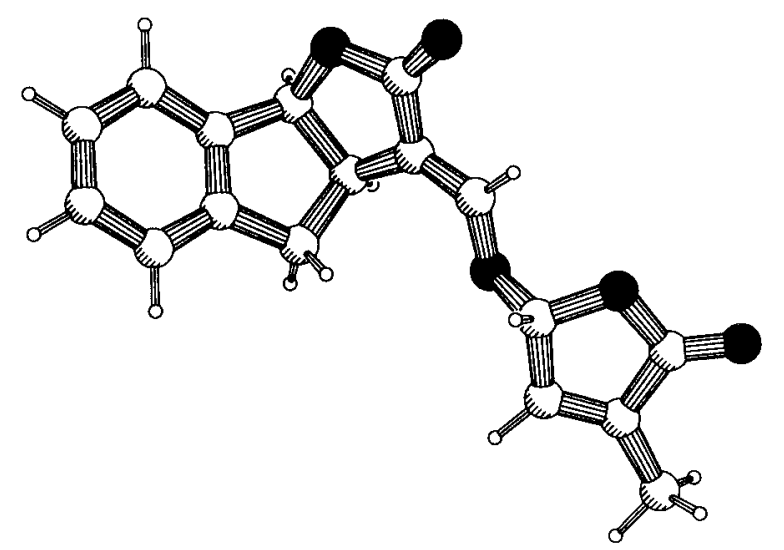

Figure 2. PLUTON-generated drawing of X-ray crystal structure of $\mathbf{2 a}$.

Table 1. Germination Percentages for Seeds of S. hermonthica after Exposure to Solutions (0.1 and 0.001 $\mathrm{mg} / \mathrm{L}$ ) of GR24 Enantiomers 2 and the Corresponding Racemic Mixture of Diastereomers rac $2^{\mathrm{a}}$

\begin{tabular}{ccccc}
\hline entry & compound & $\begin{array}{c}\text { configuration } \\
\text { at C-2 }\end{array}$ & at $10^{-1} \mathrm{mg} / \mathrm{L}$ & at $10^{-3} \mathrm{mg} / \mathrm{L}$ \\
\hline 1 & $\mathbf{2 a}$ & $\mathrm{R}$ & $56.2 \pm 4.6$ & $32.5 \pm 4.5$ \\
2 & ent $\mathbf{2 b}$ & $\mathrm{S}$ & $40.8 \pm 2.5$ & $0.7 \pm 0.4^{\mathrm{b}}$ \\
3 & ent $\mathbf{2 a}$ & $\mathrm{S}$ & $4.0 \pm 0.6$ & $0.5 \pm 0.5^{\mathrm{b}}$ \\
4 & $\mathbf{2 b}$ & $\mathrm{R}$ & $54.0 \pm 2.6$ & $0.4 \pm 0.4^{\mathrm{b}}$ \\
5 & rac $\mathbf{2}^{\mathbf{c}}$ & $\mathrm{R} / \mathrm{S}$ & $47.1 \pm 3.9$ & $33.2 \pm 2.2$
\end{tabular}

a The data presented \pm SE are from one representative experiment. ${ }^{b} \mathrm{~N}$ ot significantly different from aqueous control (without stimulant). c Equimolar mixture of two racemic diastereomers.

concentration $(0.001 \mathrm{mg} / \mathrm{L})$. It was anticipated that the latter should exhibit more profound differences. Relevant data are collected in Table 1.

The same stereoisomers were al so tested for stimulant activity on seeds of $\mathrm{O}$. crenata, using four concentrations. The results are shown in Figure 3.

These data (Table 1; Figure 3 ) reveal that there is a significant difference in stimulatory activity among the four stereoisomers. For both parasitic species, the enantiomer of GR24 possessing the "natural" absolute stereochemistry, viz. $\mathbf{2 a}$, is considerably more active than its optical antipode ent $\mathbf{2 a}$. The difference in activity amounts to at least a factor of 100 . The rel ative importance of the different stereogenic centers can be addressed by comparison of the bioactivities of the 


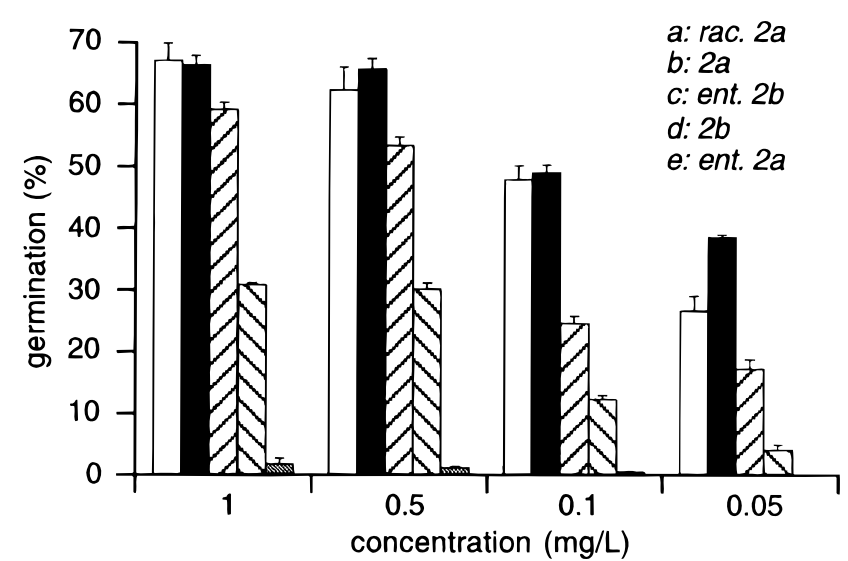

Figure 3. Germination percentages for seeds of $O$. crenata after exposure to different concentrations of GR24 enantiomers 2. The data presented \pm SE are from one single representative experiment.

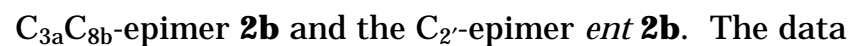
in Table 1 (entries 2 and 4 ) reveal in the case of $\mathrm{S}$. hermonthica a slight preference for the correct stereochemistry at $\mathrm{C}_{2^{\prime}}$. In contrast, the data obtained for $\mathrm{O}$. crenata (Figure 3) suggest that for this species the absolute configuration at $\mathrm{C}_{3 \mathrm{a}} \mathrm{C}_{8 \mathrm{~b}}$ is more important for the stimulatory activity than the configuration at $\mathrm{C}_{2}$. This result is in contrast with data obtained from a comparative study of GR7 stereoisomers, which revealed a more profound role of the $\mathrm{C}_{2^{\prime}}$-configuration (Mangnus and Zwanenburg, 1992). This discrepancy indicates that one cannot attribute the configuration of a particular stereogenic center as solely relevant for the biological activity by disregarding the entire threedimensional structure. Because GR7 lacks the A-ring, its smaller BC-part is apparently more flexible with respect to interactions within the receptor cavity. This implies a less critical requirement for its absolute configuration in comparison with the ABC-fragment of GR24.

Concluding Remarks. Two routes for the asymmetric synthesis of all four stereoisomers of GR24 have been presented. The route that requires the homochiral latent D-rings $\mathbf{6}$ and ent $\mathbf{6}$ is generally applicable in the enantioselective synthesis of strigol analogues. The relative importance of the absol ute configuration at the different stereogenic centers in GR24 for the germination stimulatory activity has been assessed, indicating that the molecular shape is determined by the combination of all stereocenters.

\section{ACKNOWLEDGMENT}

We thank Dr. F. M. F. Zaitoun for supplying Orobanche seeds. We also thank E. Kuiper (Free University of Amsterdam) for performing the bi oassays on S. hermonthica. We also thank H. Amatdjais, P. van Galen, and A. Swolfs for conducting el emental analysis, mass, and $400 \mathrm{MHz}{ }^{1} \mathrm{H}-\mathrm{NMR}$ measurements, respectively.

\section{LITERATURE CITED}

Bergmann, C.; Wegmann, K.; Frischmuth, K.; Samson, E.; Kranz, A.; Weigelt, D.; Koll, P.; Welzel, P. Stimulation of Orobanche crenata seed germination by $(+)$-strigol and structural analogues. Dependence on constitution and configuration of the germination stimulants. J. Plant Physiol. 1993, 142, 338-342.
Brooks, D. W.; Bevinakatti, H. S.; Powell, D. R. The absol ute structure of (+)-strigol. J . Org. Chem. 1985, 50, 3779-3781.

Cook, C. E.; Whichard, L. P.; Turner, B.; Wall, M. E.; Egley, G. H. Germination of witchweed (S. lutea Lour.): isolation and properties of a potent stimulant. Science 1966, 11891190.

Cook, C. E.; Whichard, L. P.; Wall, M. E.; Egley, G. H.; Coggan, P.; Luhan, P. A.; McPhail, A. T. Germination stimulants II. The structure of strigol-a potent seed germination stimulant for witchweed (Striga lutea Lour.). J . Am. Chem. Soc. 1972, 94, 6198-6199.

Francotte, E.; Lohmann, D. Analytic and preparative resolution of racemic $\gamma$ - and $\delta$-lactones by chromatography on cellulose triacetate. Relationship between elution order and absolute configuration. Helv. Chim. Acta 1987, 70, 15691582.

Frischmuth, K.; Wagner, U.; Samson, E.; Weigelt, D.; Koll, P.; Meuer, H.; Sheldrick, W. S.; Welzel, P. Configurational assignment at $\mathrm{C}-2$ ' of some strigol analogues. Tetrahedron: Asymm. 1993, 4, 351-360.

Hauck, C.; Schildknecht, H. Separation of enantiomers of the germination stimulant strigol on cellulose triacetate and determination of their biological activity. J . Plant Physiol . 1990, 136, 126-128.

Hauck, C.; Muller, S.; Schildknecht, H. A germination stimulant for parasitic flowering plants from Sorghum bicolor, a genuine host plant. J . Plant Physiol. 1992, 139, 474-478.

Heather, J. B.; Mittal, R. S. D.; Sih, C. J. Synthesis of the witchweed seed germination stimulant (+)-strigol. J . Am. Chem. Soc. 1976, 98, 3661-3669.

J ohnson, A. W.; Roseberry, G.; Parker, C. A novel approach to Striga and Orobanche control using synthetic germination stimulants. Weed Res. 1976, 16, 223-227.

J ohnson, A. W.; Gowda, G.; Hassanali, A.; Knox, J .; Monaco, S.; Razawi, Z.; Roseberry, G. The preparation of synthetic analogues of strigol. J . Chem. Soc., Perkin Trans. 1 1981, 1734-1743.

Mangnus, E. M.; Zwanenburg, B. Synthesis, structural characterization, and biological evaluation of all four enantiomers of strigol analogue GR7. J . Agric. Food Chem. 1992, 40, 697-700.

Mangnus E. M.; Dommerholt, F. J .; de J ong, R. L. P.; Zwanenburg, B. Improved synthesis of strigol analogue GR24 and evaluation of the biological activity of its diastereomers. J . Agric. Food Chem. 1992a, 40, 1230-1235.

Mangnus, E. M.; Stommen, P. L. A.; Zwanenburg, B. A standardized bioassay for evaluation of potential germination stimulants for seeds of parasitic weeds. J . Plant Growth Regul. 1992b, 11, 91-98.

Moers, F. G.; Smits, J . M. M.; Beurskens, P. T.; Thuring, J . W. J. F.; Zwanenburg, B. Crystal and molecular structure of (3aR,8bS,5'R)3-[2,5-dihydro-3-methyl-2-oxo-5-furanyl)oxymethylene]-3,3a,4,8b-tetrahydroindeno[1,2-b]furan-2one. J . Chem. Crystallogr. 1995, 25, 429-432.

Musselman, L. J ., Ed. Parasitic Weeds in Agriculture Vol. I. Striga; CRC Press: Boca Raton, FL, 1987; 317 pp.

Nefkens, G. H. L.; Thuring, J . W. J . F.; Zwanenburg, B. A novel and improved synthesis of 3-methyl-2(5H)-furanone. Synthesis 1996, submitted for publication.

Parker, C.; Riches, C. R. Parasitic Weeds of theWorld: Biology and Control; CAB International Press: Wallingford, Oxon, U.K., 1993; $332 \mathrm{pp}$.

Pepperman, A. B.; Dailey, O. D.; Vail, S. L. Biological activity of strigol, its precursors and its analogs. In Synthesis and Chemistry of Agrochemicals; Baker, D. R., F enyes, J. G., Moberg, W. K., Cross, B., E ds.; ACS Symposium Series 355; American Chemical Society: Washington, DC, 1987; pp 445-461.

Press, M. C.; Graves, J . D.; Stewart, G. R. Physiology of the interaction of angiosperm parasites and their higher plant hosts. Plant, Cell Environ. 1990, 13, 91-104.

Siame, B. A.; Weerasuriya, Y.; Wood, K.; Ejeta, G.; Butler, L. G. I solation of strigol, a germination stimulant for Striga asiatica, from host plants. J . Agric. Food Chem. 1993, 41, 1486-1491. 
Thuring, J. W. J. F.; Nefkens, G. H. L.; Schaafstra, R.; Zwanenburg, B. Asymmetric synthesis of a D-ring synthon for strigol analogues and its application to the synthesis of all four stereoi somers of germination stimulant GR7. Tetrahedron 1995, 51, 5047-5056.

Received for review J une 28, 1996. Revised manuscript received J anuary 2, 1997. Accepted J anuary 9, 1997. ${ }^{\otimes}$ These investigations were supported by the Netherlands Foundation of Chemical Research (SON) with financial aid from the Netherlands Organization for the Advancement of Research (NWO).

J F960466U

${ }^{\otimes}$ Abstract published in AdvanceACS Abstracts, April $1,1997$. 